\title{
Bordering Wastelands
}

\author{
Kateryna Pashkovska \\ PhD Candidate at the Department of Anthropology, University of Alberta \\ Address: 116 St. and 85 Ave. Edmonton, Alberta T6G 2R 3 Canada \\ E-mail: pashkovs@ualberta.ca
}

\begin{abstract}
In this anthropological study, I examine how a particular state and regional border is crossed in the context of a joint socio-ecological project concerning recycling waste in Karelia. During a two-year, multilevel project, cooperation developed between the Petrozavodsk municipality and its northern partners under the auspices of the Nordic Council of Ministers. This cooperation was advanced particularly through the eastward translation of values, including early education and sustainable behavior, which were consistent within broader international border relations across the Barents Euro-Arctic Region. The process of the taking over of these imported Nordic values and knowledge, and adapting them to the everyday and professional life of the local participants of the project went hand in hand with the perpetuation of cultural cross-border stereotypes. The idea of marking home from foreign became equally applicable to the space within a much smaller entity, such as a condominium, a round-table in a discussion room, or a city flowerbed, particularly when the construction of the border intersected with the construction of the other. Invisible barriers, as well as physical objects, can demarcate the divide between individuals of the same nationality and cultural background who need to claim, protect, and reconstruct a personal connection to a piece of land.
\end{abstract}

Keywords: postsocialism, recycling, sustainability, Nordic values, translation and adaptation of values, construction of the other, Barents Euro-Arctic Region, Karelia

\section{Introduction}

State and regional borders are regularly crossed for multiple reasons and purposes including the flow of both people and trade, and involve political security, entrepreneurship, and law, which represent the major concerns in border studies. At the same time, border research focused on migrating ideas, identities, values, attitudes, and priorities; power imbalances receives far less attention. As M. Wilson and H. Donnan put it, "Anthropologists approach these borderlines more as countless points of interaction, because the borderline is there, or in spite of it" (Donnan, Wilson, 2010: 8). It can be argued that less tangible instances of cross-cultural communication that parallel specific activities in cross-border cooperative projects and initiatives are quite influential factors affecting the projects' outcomes. This view is shared at the highest political level within the Barents Euro-Arctic Region (BEAR), which is manifested in the conscious and deliberate attempts to create a common regional identity and sense of community among its inhabitants. ${ }^{1}$

(C) Kateryna Pashkovska, 2014

(C) Centre for Fundamental Sociology, 2014

1. From the very start of the political Barents project, Norwegian Foreign Minister Thorvald Stoltenberg tried to present a broadly imagined rationale for constructing the new region. As such, he justified his initiative as a restoration of historical relations between Northern Norwegians and Northwestern Russians (Thor- 
The Barents Region houses the international project WASTE: Waste Awareness. Sorting, Treatment, Education (2011-2013), located in Petrozavodsk, Karelia, and is the case study addressed in this article. ${ }^{2}$

One characteristic feature of the BEAR is that it is a region and an organization at the same time. Its functioning as an organization is not problematic when it involves cooperation on the highest level of the Barents Council, along with a number of projects realized by different regional structures. Still, there are a number of factors that hinder cross-border cooperation. One of them is the common border between Russia and its northern neighbors. The border is not only a demarcation line separating Russia from the countries of the Northern Council of Ministers, and the line dividing Russia and the European Union, but also a frontier between Russia and NATO. This context has had a significant effect on the original, and to some extent current, rationale for the Barents Council that continues to be an instrument of normalizing relations between former and current rivalries in the economic and military sphere. At the same time, the Barents region is evolving and constantly changing (Hettne, 2002), providing an important platform not only for socially meaningful projects, but also for regional security and peace building. This is why it would be unwise to undermine the peacekeeping capacity of the Barents Region.

The project WASTE lasted for two years, from 2011 until 2013; the year before the project began, I was in Petrozavodsk where I had the opportunity to observe WASTE in its pilot stage, as well as to familiarize myself with the pool of other international social and cultural projects underway, and to talk with participants. The data underpinning my analysis was collected through structured, unstructured, and spontaneous interviews with local people in Petrozavodsk who were involved in the project. These people included officials engaged in social work or in the local government, as well as with people not directly involved who had opinions about the project and were willing to share them with me. In total, I spoke with eighty-two people and conducted about two hundred interviews with them. I should admit that my results are most representative of the Karelian capital, Petrozavodsk, and does not necessarily extend to the whole republic, which is clearly divided into the center and the periphery. However, these locally bounded conclusions lead to potentially interesting generalizations addressed below.

vald Stoltenberg, Foreword in: Stokke, Tunander, 1994; Stoltenberg, 1997). He perceived it as necessary to come up with some sort of "glue" that would secure the newly drawn regional lines and would bridge the territories that are so different in terms of societal norms, culture, politics, religion, and language. Mr. Stoltenberg appealed to the Pomor trade era that was chosen to be a symbolic consolidating factor. The Pomor era was a period of relatively peaceful and mutually beneficial trade between the Norwegian, Russian and a few Finnish settlements along the shore of the Barents Sea (Nielsen, 1994: 91). However, it is doubtful that there was a real need for this intensive construction of a common identity stimulated by the political objective to make the regional cooperation happen (Bærenholdt, 2007).

2. The international environmental project WASTE. Waste Awareness: Sorting, Treatment, Education (2011-2013) is a follow-up of a pilot project for the introduction of waste sorting methods in Petrozavodsk (2009), realized by the City Administration of Petrozavodsk under the auspices of the Nordic Council of Ministers. 
In my position of a researcher, I embodied the dichotomy between insider and outsider. My identity was mixed, depending on several key personae I interacted with, and which I indexed depending on the context. For example, for the migration office in Karelia I was a representative of a Canadian university with proper documents and reference letters needed to ground my prolonged stay in Karelia. The use of my native language of Russian allowed me to be embraced as "almost local," while my position of a volunteer in the project set the ground for open communication with other participants.

The larger outcome of the WASTE socio-ecological project, as well as similar sociallymeaningful projects and programs, has been the "softening" of international borders, and setting a foundation for cooperation in more politically sensitive areas including the use of natural resources, or common security, for example. One of the meeting points of social, cultural, ecological, or network projects that is deemed "politically neutral" is the collaboration based on a set of mutually acceptable common values that forms a binding agent.

So what are those common priorities shared by the Nordic countries that are reflected in policy documents, in the foci of cooperative programs and projects, and in the rate of funding? Are they in accordance with the local Karelian realities, and do they have a chance to get rooted in this territory? The primary sources delineating the policies of the northern countries under the Nordic Cooperation, as well larger European partnership, converge in naming green development, education, civic society participation, and entrepreneurship as the most important items of the agenda. Thus, the position stated at the home web page of the Norden (cooperation between the northern European countries) refers directly to commonly shared values as the core and the starting point of partnership. ${ }^{3}$ For Karelia, the topic of environmental protection became acute with a number of accumulated problems including improper waste-water treatment, the dire condition of the Petrozavodsk landfill and a great number of spontaneous (and unauthorized) landfills in the countryside, air and water pollution, etc. At the same time, the public's readiness to take part in resolution of ecological issues grew proportionately to the awareness of them.

3. The welcoming statement reads, "The political cooperation is built on common values and a willingness to achieve results that contribute to a dynamic development and increase Nordic competencies and competitiveness" (available at: http://www.norden.org/en/about-nordic-co-operation (accessed 13.09.2014)). For other sources on the Nordic priorities and fields of cooperation please see documents like The Nordic Welfare Model, OECD publications on sustainable development, Norway's Strategy for Sustainable Development, Sustainable development: National Agenda-21 for Norway, Priorities for Norway voiced at the UN General Assembly in 2012, etc. Gerd Vidge. 2013. The Nordic Welfare Model. Nordic Center for Welfare and Social Issues. Available at: http://www.nordicwelfare.org/PageFiles/7117/Nordic_Welfare_Model_Web.pdf (accessed on 20.09.2014). Sustainable Development: Linking Economy, Society, Environment. 2008. OECD publication. Available at: http://www.oecd.org/insights/sustainabledevelopmentlinkingeconomysocietyenvironment.htm (accessed 10.08.2014). Norway's Strategy for Sustainable Development. Norwegian Ministry of Finance, published as Part of National Budget of 2008. Available at: http://www.regjeringen.no/upload/FIN/rapporter/R0617E.pdf (accessed 15.08.2014). National Agenda-21 for Norway in sustainable development. Available at: http://www.regjeringen.no/en/dep/fin/Documents-and-publications/Guidelines-and-brochures/2005/Sustainable-Development-National-Agenda-.html?id=419468 (accessed 16.06.2014). Priorities for Norway at the UN General Assembly in 2012. Available at: http://www.regjeringen.no/en/dep/ud/selected-topics/un/priorities_assembly67.html?id=699661 (accessed 15.06.2014). 
As Dmitry Rybakov, the head of the Association of the Green of Karelia noted, "Our cocitizens start to realize their own responsibility for the environment which reveals in the fact that now it is much easier to mobilize them for eco-campaigns in the city than, say, five years ago." 4

\section{Behind the Line on the Map}

However, the BEAR is not the only successful framework for international projects in Karelia. Every year, numerous programs and projects are developed and realized through the cooperation in the Baltic Sea Region, region-to-region initiatives, projects between Petrozavodsk and its sister towns, projects of the cross-border cooperation program Russia-EU "Karelia," projects of "contagious cooperation," etc. ${ }^{5}$ Similarly, Karelia lies within the scope of the European Union policies of Strategic Partnership with its external eastern neighbors, a policy that is named among the key priorities by the European Commission (2000). Other platforms include the cross-border cooperation (CBC), and the developing European neighbourhood policy (ENP).

Gerald Blake (2010) developed a set of criteria to determine the condition of an international border as being under stress or without stress. Application of these criteria to the Karelian-Finnish border reveals that it can be characterized as a relatively soft border. There are no active territorial disputes, and the intensity of flow of people and goods in both directions is comparable. The local governments and municipalities are engaged in active cooperation with partners across the border (the majority of it meaning cooperation being with Finland) in regards to social and cultural projects, as well as infrastructural maintenance. Particular attention is given to environmental concerns. This is a "safe," non-political area, unanimously acknowledged as an important focus in the light of the deteriorating environment in Karelia. Its northwestern neighbors are quite concerned about this, and have no illusions as to the inability of a human-drawn borderline to contain the boundaries of pollution. The partnership in this sphere also involves combating water, air, and ground pollution, as well as cooperating in rescues, and a forest-sector task force. ${ }^{6}$ In short, cross-border interactions in Karelia can serve as illustration to the idea voiced by Esklinen et al. (1999) about the changing scale of cooperation, with the focus on power shifting from central governments to regional and local bodies.

It is important to situate my study of a socio-ecological joint project designed to benefit a local Karelian community within the larger scale of inter-regional relations and the specifics of the Barents region as a product of new regionalism (Keating, 1998; Hettne, Inotai, 1994; Hettne, 2003) and the product of a new post-Cold War era. As such, it de-

4. Interview, June 2014.

5. The author is grateful for the reports about international cooperative projects in Petrozavodsk for the period 2010-2013 to the Ministry of Economic Development of the Republic of Karelia and personally to senior specialist A.M. Zvetkov.

6. Barents Euro-Arctic Council. Available at: http://www.beac.st/in-English/Barents-Euro-Arctic-Council/Working-Groups (accessed 15.06.2014). 
lineates the borders that separate Russia and the Nordic countries, i.e., it highlights the distinctiveness of political, economic, cultural, and social systems of each.

Currently, during a period of mutual economic sanctions adopted by Russia and Europe on the basis of Russia's government's external policy in regards to Ukraine, the political relations between Russia and Finland remain consistently warm with no changes in the border-crossing policies. In Hastings' and Donnan's terms, "the international relations litmus test" has been passed (2010: 6). Although the one-year ban on import of certain food items introduced by the Russian government hit some Finnish producers quite seriously (and probably, it was most felt by the well-known dairy company Valio), the most recent news indicates that compromises are a solution. Thus, production of Valio milk and cream will begin in a plant near St. Petersburg at the partner factory Galaktika. ${ }^{7}$ As theorized by E. Haas in 1958, true international convergence is more likely to happen as a result of societal actors cooperating through cross-border projects and networks in "soft" spheres where cooperation does not provoke extensive control and paternalism on the part of the central government. This statement is developed further on, but at this point, it can be argued that the successes of cross-border bottom-up networks and projects like WASTE work to soften the Russian-European border.

\section{Nordic Countries as a Point of Reference for Karelia}

The focus on environment and youth in the context of sustainability has been implemented through different frameworks and programs, including Youth at Risk, 2008-2015, under the Kolarctic cross-border cooperation. Strong commitments to its Russian partner were underlined by the establishment of an interregional center for methodological support in Petrozavodsk in 2012 as a major coordination office for the whole of northwest Russia. ${ }^{8}$ Among other the most relevant initiatives involving recycling are first, the Nordic strategy for collection, sorting, reuse, and recycling of textiles, and second, the Nordic Waste Group that "works toward sustainable processing of waste products in the Nordic countries and Europe," both of which platforms function through the Nordic Council of Ministers.

In spite of some criticism, Nordic countries from year to year continue to top the international rankings that assess not only custom components of well-being such as health, employment and income, safety and security, environment, education, and entrepreneurship and opportunity, but also measure even more subtle psychological and social parameters such as general life satisfaction. According to OECD's Better Life Index, Nordic countries are in the top of the list, with Norway occupying second place only to Switzerland. Finland ranked seventh. Both indices are well above the OECD average

7. Finnish Valio to begin producing milk, cream in Russia. Strategic Culture Foundation (online journal). 10.10.2014. Available at: http://www.strategic-culture.org/news/2014/10/10/finnish-valio-to-begin-producingmilk-cream-in-russia.html (accessed 12.11.2014).

8. Steering Committee on Children and Youth at Risk 2008-2015 (CYAR). Available at: http://www.beac. st/in-English/Barents-Euro-Arctic-Council/Working-Groups/Joint-Working-Groups/Health-and-SocialIssues/Children-and-Youth-at-Risk (accessed 12.10.2013). 
results. ${ }^{9}$ Such highly successful performance cannot but attract Karelia whose joint international projects aim to benefit from the positive experience of the Nordic countries, as well as their technologies and innovations in the public sphere. The Nordics have invaluable experience and a pool of technologies to spread to their eastern neighbor with different ranges of applicability from almost-inimitable (literally) eco-cities with their sustainable brand of local entrepreneurship, to small programs implementing recycling strategies, and early ecological education that are easier to replicate. ${ }^{10}$

\section{Finding Mutual Ground Around WASTE}

However, the objective need for change in the case of the catastrophic state of the Petrozavodsk landfill that was indirectly targeted by the project WASTE does not in itself guarantee a consolidated action on the part of the local authorities and society. The question that seems relevant to me in this concern is the double correlation between a) the Nordic green values and their reflection in the WASTE's goals and agenda, and b) the Nordic green values as they are represented in the project's stated goals and their practical realization in the course of the project. Some of the tangible immediate outcomes of the cooperation within the WASTE project were realized along several major directions, including the "cross-cultural translation and adaptation of values" on the level of society and individuals, changes in adult and children's behavior, measurable everyday practices towards more sustainability, and setting the base for continuing improvements in the ecological sphere in the city including cooperation between locals without foreign impetus. ${ }^{11}$ Recognition of the positive outcomes of the project resulted in the approval of a follow-up initiative (2013-2015) by the Nordic Council of Ministers that focuses on the small-scale entrepreneurship in the field of waste management in the republic of Karelia.

Finding common ground on the basis of mutually shared values is vital for crossborder cooperation between societies that differ in their political base, cultural patterns, religions, and language. The project WASTE brought together four distinct nations; Norway, Denmark, Finland, and Russia, with a number of represented European partners in accordance with the strict demands of the financing party, the Nordic Council of Ministers. The most visible barrier was the difficulty of cross-cultural communication during common seminars and training, due to the complexity of having to negotiate four different native languages. This problem was solved by inviting a high-quality interpreter in English and Russian, whose skills and expertise were repeatedly reconfirmed during each meeting. A further facilitating factor was that representatives from the four nations were

9. Better Life index, OECD. Available at: http://www.oecdbetterlifeindex.org/ (accessed 16.04.2014).

10. As an example, an article on the Swedish eco-municipality of Overtornea (Belser, 2004). But in fact, the examples are becoming more numerous throughout the whole northern Europe with the rest of EU slowly catching up.

11. A most recent example is a round table discussion about the future of separate waste collection in the Petrozavodsk urban district that took place on October 10, 2014. It was organized by the Department of Environmental protection and ecology outreach of the city administration. Availabe at: http://www.petrozavodskmo.ru/petrozavodsk/index/news/more.htm?id=10766268@cmsArticle (accessed 11.10.2014). 
together only occasionally at larger events, while the bulk of common practical activities was organized by a Petrozavodsk city administration in partnership with SYKLI, the Environmental School of Finland, Helsinki. Besides the generally good cultural understanding between the Karelians and the Finns, the coordinator on the Finnish side was a native Russian speaker and a former Petrozavodian citizen.

\section{Importing or Exporting Values}

It would be a demanding, ambitious, and virtually impossible task for a researcher to try to determine whether any conscious attempts from the side of a sponsoring agency were made in order to import (or export) its particular values and beliefs. Thus, my primary sources used to locate unconsciously promoted messages and suggestions include written documentation produced in the course the project, both official as well as informal oral communication that occurred between the participants at gatherings and events ${ }^{12}$, and structured interviews with participants, local officials, and ordinary people not directly involved. It should be noted that none of the public relations (PR) materials targeted at the general public, including brochures for educators and handouts for the associations of homeowners, included any specific references to "Nordic values" or "priorities." The need for recycling, along with its moral imposition and its potential economic gain, was postulated as a purely local concern and citizens' mutual responsibility.

A new perspective opens up if we introduce the category of degrees of disclosure of information when a particular type of message is selectively revealed to particular groups of people who are involved in the project in one or another capacity. The key points were highlighted quite differently in some project descriptions aimed at the Nordic Council of Ministers in PR materials, and in interviews with media. For example, in one of the official descriptions of the project that was not immediately available to the general public, it was stated that one of the goals was to introduce Nordic environmental technologies and environmentally-adapted solutions for the Russian market. Alternatively, the goal of educating citizens of the chosen settlements in applying methods of waste sorting and raising public awareness of the importance of eco-friendly behavior was widely distributed through all possible media to anyone interested in the project. Achievement of the earlier goal most likely meant profit for the Nordic partners and is in line with the followup project on the entrepreneurship in the field of waste collecting, sorting, and recycling in Karelia. At the same time, different means were developed and introduced for the realization of the latter goal that would involve interaction with the local society at the larger scale that was initially outlined. Interestingly, the cooperation with kindergartens added after the project was underway was not in the original plan at all. Ultimately, it proved to be one of the most productive directions taken by the project.

12. I personally attended all gatherings and events except for the final stage, which I observed remotely. 


\section{Petrozavodsk as a Gateway to the West}

In general, Petrozavodsk is fertile ground for inclusion in the broadly defined "western values." In many respects, the Nordic countries are the point of reference for neighboring Karelia due to a number of factors, including a long history of a shared border with Finland, which presently also means a common border with the European Union that is regularly and, for the most part, quite easily crossed. The European presence is obviously felt in Petrozavodsk with its monuments belonging to the contemporary art on the quay (gifts of sister towns), selection of restaurants, and available cuisines. The European influence is heard in the Nordic languages spoken on the streets, in the repertoire of the local cinemas, found in museums and art centers, and in the wide selection of goods from detergents to adult and children's clothing. Because of the long and cold winters, many local parents consider it a badge of honor to dress up their child in overalls or in either new or second-hand two-part costumes from well-respected Finnish brands including Reima, Kerri, Luhta, and Lassie.

On the one hand, at the very beginning of the pilot project, Petrozavodsk society was susceptible to what was considered, at that time, to be trendy green initiatives, and on the other hand, such empathy did not mean automatic commitment to changing one's way of life and adopting new patterns of behavior, which is a lengthy and quite complicated process. In my volunteer classes for children ages four to six in local kindergartens, as well as in my colleague's presentations for school children, we gave statistical and visual information about the dire and even dangerous condition of the landfill that was accepting solid wastes from Petrozavodsk and adjacent areas. The pictures of the site and graphic representations of the daily amounts of waste produced along with the comparable weight of tracks and even train cars always evoked emotional response on the part of the children and teachers. This sense of involvement helped keep the interest high through to the end of the educational activities for the day, but was insufficient to start a stable movement towards changing practices.

\section{Selecting Imported Values}

Solidarity with "western values" can be manifested in different ways, which are not always straightforward. Just a few days ago, I read in the city administration newsletter about the free market day (free exchange of goods and services) to be held on the upcoming weekend. This event is coordinated through a public group on the platform of the social network VKontakte. The group names its physical location in Petrozavodsk, where it gathered 591 members on October 10, 2014. Its slogan reminded me that anti-capitalist and downshift philosophy also have a Western origin. The slogan read: "No Money, No Trade. Capitalism must die."

The aspiration to open ground for the introduction and application of Nordic environmental technologies in waste treatment and recycling in the market of northwestern Russia can be traced historically. Since the times of the Iron Curtain, Russia was perceived 
by its Nordic neighbors, particularly by Norway, as a potential security threat (Stokke \& Tunander, 1994). With the fall of the Soviet Union, Russia's northern neighbors learned about the dire situation involved with the utilization of nuclear and other types of waste, mainly in Murmansk Oblast, which shares a border with Norway. The hazardous emissions spreading westward from the Russian territory by air and water became a concern that called for action (Dellenbrant and Olsson, 1994). Thus, in addition to improving environmental conditions in Karelia, the project also sought to open up a receptive market ${ }^{13}$ for Nordic technologies, facilities, and equipment through the transmitted knowledge base, the understanding of ecological imperatives, and the promotion of green values as they are understood in Northern Europe. Opening up new sales areas is potentially beneficial for both parties. However, to date, there are few players in the recycling business in Karelia, which was addressed by the director of the local company Ecolint in the following way; "this [collection of sorted waste with further utilization or transportation] is not a very profitable business ... From time to time, new entrepreneurs try to enter this niche but mostly fail. It is a hard work for money that is never secured." ${ }^{4}$ Perhaps, these are some of the reasons for the focus of the follow-up project on entrepreneurship in the sphere of waste management.

There are a number of challenges that hinder this process, and legal issues are among them. Under the project WASTE, there was an attempt to change the local legislation in relation to practices of waste management; this attempt failed. I hesitate to make flat assertions, but one possible reason for the failure could have been the conflict of interests between local and foreign businesses. For Russian players, such legislative lobbying could have resulted in the loss of established positions, whereas the northern partners could have seen the more favorable laws as the background for the spread of influence. At the same time, the spokes in the wheels of the new legislature could have been put there by federal officials, which would be in line with the Michael Mann $2007^{15}$ opinion of stillpowerful states. However, the true reasons for the waste treatment laws being left unchanged remain in the shadows. In other respects, federal intrusion or state bureaucracy was not felt during the project. Neither my own observations, nor the opinions voiced during interviews with project participants, suggest any problems on this level.

From my participant observation and analysis of the accompanying documents, I singled out several values emphasized in the course of the project's development that were not always directly stated. These values or priorities are; early ecological education, development of sustainable behavior of adults and children, freedom of choice as a democratic value, motivation boosters, and volunteering. I discuss some of them in greater detail below. Education and public participation are named among the key factors of sustainable development in a number of EU policy documents. ${ }^{16}$ The means of achieving sus-

13. In one report about the WASTE project (2011), it was stated that implementation of the project will help to attract Nordic companies which produce environmental technologies to the Russian market, and will contribute to the improvement of environmental conditions in the Baltic and Barents Sea areas.

14. Interview taken on 18.06.2014

15. Cited in Wilson, Donnan, 2012: 17.

16. See, for example, 2009 Review of the EU Sustainable Development Strategy (Presidency report). 
tainable development in this case remained the same as developed European countries, including the establishment of the grounds for ecological modernization, transition to energy-effective and resource-saving production models, new technologies and forms of management, and the spread of ecological socialization and education. In this sense, the project WASTE was directed to sustainability.

\title{
Early Ecological Education
}

During my talks with educators from schools and kindergartens, no one voiced the opinion that, for children, acquaintance with environmental topics was useless. In fact, ecological education is a part of new methodological policies of the federal ministry of education; it is notable that ecological education is now obligatory for junior educational institutes. At the same time, doubts regarding the value of participation in the project were conditioned by other priorities and current activities of particular kindergartens. It is true that except for the classes given by volunteers, neither schools nor kindergartens would have included games and activities devoted to waste sorting. Ecological lessons in preschool are broadly associated with cute animals and vulnerable greenery that call for help on the child's part, as well as a set of rules or limitations that s/he must follow while outside in order not to harm wildlife. In light of this approach, the topic of waste is easily dismissed as outside the sphere of early education ecological training to the point of being discreditable.

Three kindergarten teachers whom I talked to in connection to the project made comments along these lines, stating that

\begin{abstract}
. . . why would we want our children to dig into litter containers? Parents won't appreciate this ... no matter how well you wash it, it's dirty! I think it's an upright violation of hygiene norms [in response to my comment that all used plastic bottles and cans distributed to children for play and activities are rigorously washed]; many children in our kindergarten come from better-off families ... I don't think that the parents will understand why we can't play with new toys and have to make handicraft from used material.
\end{abstract}

None of these women, nor the establishments they represented, decided to participate in the project. The private comments that I got seem to be directly related to the topic of garbage and purity in Anthropology, and primarily, to its pioneer, Mary Douglas (2005).

As it was revealed later on, similar considerations played a significant part in the decision of some educational institutions that already had begun participation to withdraw

Available at: http://register.consilium.europa.eu/doc/srv?l=EN\&f=ST\%2016818\%202009\%20INIT (accessed 5.05.2013); Communication from the Commission to the European Parliament, the Council, the European Economic and Social Committee and the Committee of the Regions-Mainstreaming sustainable development into EU policies: 2009 Review of the European Union Strategy for Sustainable Development. Available at: http://eur-lex.europa.eu/legal-content/EN/TXT/?uri=CELEX:52009DCo40o (accessed 12.06.2014); home page for Environment of the European Commission. Available at: http://ec.europa.eu/environment/eussd/ (accessed 15.04.2014). 
from the project. In this process, I became a witness of the construction of a double boundary. First, these negative attitudes set a partition around what should not be allowed in their kindergarten space, and what became labeled as impure and even troublesome. This boundary separated the children who would not have a chance to learn about some aspects of their surrounding reality from those who would have because they found themselves included in a different social paradigm. Also, this boundary separates $u s$, educators who stand for "what is appropriate for kids" from them, the strange inhabitants of other kindergartens who do not share these obvious maxims. Or, the other way around, it is a dividing line between $u s$, the open-minded pedagogues of a new generation ${ }^{17}$, and them, our ecologically indifferent colleagues who do not have the courage to open their eyes to the truth of real environmental problems around us. I have to admit that I did not conduct separate research to explore this hypothesis further, which is based on five informal talks with kindergarten teachers and their head-mistresses. Nevertheless, these voiced attitudes open up an important perspective on the internal factors that have a possibility to hinder or support the waste recycling initiatives in the region.

\section{Head-Administators and Subordinates: Guarding Personal Borders}

Investment in innovations is another value that can be certainly called one of the Nordic priorities and that finds its realization in the project WASTE. It should be noted that participation in this project by teachers from schools and kindergartens means taking over responsibilities for extra-curriculum activities. Performance of these obligations, as a rule, is shared in the following way; the head of the kindergarten is responsible administratively, and a particular educator, or educators, bear the bulk of work on their own shoulders with an average extra pay of 500-700 rubles per month. ${ }^{18}$ I encountered a few successful exceptions to this, when a head administrator, one who took children's education in recycling wastes to heart, shouldered the major responsibility for the kindergarten's participation, and coordinated all activities personally. However, this situation may become motivationally discouraging for counselors and assistants as much as the burden of sole responsibility.

The division of power and roles between the head administrators and their subordinates definitely plays out in their relations and organization of work. Thus, the choice of a teacher to go on a study trip was not always straightforward and was left to the discretion of the head administrator. Often, several teachers were working on the implementation of the project's activities in a particular kindergarten, and the choice of only one person to go on a trip abroad (as required by the sponsor) occasionally produced tensions inside the group, especially if the input of each participant was relatively equal.

17. Interestingly, I found that the age category is not meaningful in this context. Elderly teachers could exhibit as much openness to innovations and flexibility as the lack of these from the side of recent graduates of pedagogical institutions.

18. 500 rubles is roughly $\$ 13$. The information is received from the interviews with heads and educators in participating kindergartens. The principle of confidentiality applies to their shared opinions and specific figures. 
The majority of head administrators was hesitant to occupy the spot, and had the teachers go on the trip. Among responses elicited to the question of the principles surrounding the choice-making, the head administrators consistently mentioned such reasons as the teachers' comparatively lower salaries; the teachers' young(er) ages and the need to "see the world" that was in opposition to giving credit to the more experienced teacher; the "justice factor," that is, the one who works, goes on a trip, etc., saying "She's [a teacher] fresh from college and it will be good to motivate her with a trip," or "this is our most experienced teacher and she must be rewarded for her work," or "in our team, she's the most active participant, so it would be fair to send her." I should note here, that in the case of the "encouragement motif," the study trip appears to have lost its attributive adjective of "study," and focused on a sense of fun and relaxing occasion, the "trip" part of "study trip." In an interview conducted in 2010, a newly-minted politician in the Petrozavodsk local government who came from the youth policy field, made a point of his party's campaign directed toward advancing opportunities for regular employees instead of head administrators, who had often and extensively misused their office. This can be one of the reasons for the kindergarten administrative heads' cautious words and deeds, and the overwhelming choice of a teacher rather than a head administrator to take the study trip.

The evidence supporting the existing practice of involving high ranking participants as opposed to lower ranking ones without formal affiliation can be found in examining the list of participants of the international projects in Karelia that involve study trips. One example is a project named "Development of Youth Entrepreneurship Through the Partnership Network of North-west Russia and the Nordic countries" (2011), financed by the Nordic Council of Ministers. Out of the eight participants who went on the study trip, there was not a single young entrepreneur. Instead, the pool of participants consisted of two local government officials, three representatives of high educational establishments of Petrozavodsk, one high-ranking representative of the municipal youth occupation development center, the project's administrator, and a media coverage person.

My research shows that the best politics in choosing participants would be to use a weighted analysis in each particular case, that is, it would be most politic to use an individual approach. Thus, coming back to the project WASTE, only one kindergarten administrative head went on the mentioned study trip feeling the full right to do so. This individual was involved in a partnership with a couple of Finnish kindergartens long before the project commenced, and had vast experience in organizing ecological and other thematic activities for her own children. She had established collaborations with other local kindergartens, eagerly implementing new knowledge and approaches taken up from her Finnish friends. One of the bravest innovations of this kindergarten under the leadership of its head administrator was the practice of having sleep-over nights, unique for Petrozavodsk. This was an organized event for children over five years of age attending the kindergarten. Several times a year, they had an opportunity to stay for the night at their kindergarten to celebrate a kind of independence (under the care of their teachers), and have a tea-party followed by an hour of story-telling before going to sleep in the beds they usually occupied at nap time. This particular kindergarten's head ad- 
ministrator represents an excellent example for the need of an individual approach in the analysis of power relations, and the degree of openness of opportunities for employees. This individual took the participation in the waste recycling project to heart, and numerous examples of her creative approach and untiring activity was felt in every corner of the kindergarten entrusted to her care.

\section{Expectations and Perceived Outcomes: Poorer vs. Wealthier Schools}

One final aspect that attracted my attention while doing my fieldwork was the difference in conceptual positions of the kindergartens that actually plunged into the work in the project. These positions can be broadly defined as a "thumbs-up optimism of the poor," and a "skepticism of the rich." Specifically, these positions refer to the personal estimations of the kindergartens' representatives regarding the possible outcomes from participation in the project. Roughly, the two opposing positions in their extreme forms, as elaborated in the interviews, can be described as follows. The first one represents the extremely optimistic view of the effects that participation in the project will bring in the spirit of "keep my eyes on the prize." In this, much of the success devolved onto the good will of children and parents who were supposed, in the minds of interviewees, to unanimously support the idea of the turning to separating wastes not only in the kindergarten, but also at home, and to be ready to use all trash material for crafts and help the kindergarten win prizes, including money for implementation of particular recycling projects, as well as merit certificates important for the institution's prestige. Such a view was voiced almost exclusively by those who, in my estimation, were in the most poorly equipped kindergartens. The opposite view, in the spirit of "the way is full of pitfalls but we will try," refers to the kindergartens that were extremely active, participating in a number of municipal and international projects, and which regarded the WASTE project as one of many initiatives in which they were already involved. For them, it was very important to make sure beforehand that the benefits of participating were greater than the expenses; the final decision was coldly made on the basis of such an analysis.

\section{Constructing the Other}

"Borders have and will continue to serve as barriers of exclusion and protection, marking home from the foreign. In this sense they still provide the function of separation and defense that is expected of them" (Donnan, Wilson, 2010: 11). Although the authors wrote this about nation state borders, the idea of marking home from foreign is equally applicable to the space within a much smaller entity, such as a condominium, a round-table in a discussion room, or a flowerbed, if the construction of the border intersects with the construction of the other. Below, I discuss three examples of different types of such constructions; how members of an association of homeowners can become insiders or outsiders in their own apartment house depending on their recycling behavior; the way in which cross-cultural stereotypes are perpetuated at international meetings in the city 
administration and get reflected later on by the media; and the way in which municipal ecological campaigns frame "us vs. them" on the smallest piece of land one could imagine.

\section{The Passion of Trash Containers}

One of the adult target groups in the project WASTE were the leaders and residents of condominiums in particular districts in Petrozavodsk where recycling stations were already installed or were planned to be installed. In my talks with this category of project participants, we touched upon a number of aspects of sorting household wastes and the obstacles that were faced along the way. An unexpected and recurrent topic that emerged in many of the interviews with residents of different apartment blocks was the boundary erected between residents of the same condominium. The categories of $u s$ versus them were introduced depending on the degree and quality of residents' participation in the waste sorting in the yards of their apartment blocks:

We took pains to become members of the project and have the bins installed ... I, personally, put up notices for residents with instructions how to use them [the bins], tell them about our common gatherings ... You think they come? You think they make an effort not to confuse a glass bin with a plastic one? Well, many of them do, but those who don't ... They're renting here and don't care at all ... Some of apartment owners also are having a hard time understanding what it is all about. ${ }^{19}$

Another leader was outraged by the mess around the recycling station in his yard:

Look, look here! It's all messed up! I got a notice from Avtospestrans [the municipal company that was responsible for recycling stations at that time] that in our bins the wastes are mixed! People use improper containers. I think, even children could have learned by now . . . I can name all my neighbors who do it right and those who mess with it. ${ }^{20}$

As much as a commitment to separate waste collection was initially a solidifying factor among the residents of one building block, it simultaneously drew a line between those who conformed and those who did not care. In response to my question about the means of locating all the "delinquent neighbors," one leader, D.V., clarified that he spent a couple of hours in the mornings and in the evenings watching the recycling station from his apartment window. During the day, several "responsible old ladies" were taking over. Several months following the installation of recycling stations, the neighbor relationship within the two apartment blocks that I studied became considerably strained.

19. A. S., a head of one of condominiums participating in the project.

20. D. V., a head of a participating condominium. 


\section{Polluting Russians and Baffled Europeans: Constructing Us vs. Them}

The issue of separate waste management is not only discussed at round-tables and seminars that are specifically devoted to this topic. The recent seminar in honor of Mr. Egon Bahr became a platform for cooperative cross-cultural problem-solving in the spheres of ecology and youth politics in Karelia, when young Russian and German politicians and community workers came together. In this case, it was the copy-writers from the city's administration web-site who participated in another instance of the construction of $u s$ versus them. According to the report of the seminar, its foreign participants were very surprised to find out about the infamous numerous unauthorized landfills in Petrozavodsk. "It was unclear for Europeans how one can consciously litter and make dirty one's own city." ${ }^{21}$ In this story, the Europeans are represented as not even understanding the facts of littering that indeed, perhaps, is more common in Russia than in Germany. It also bears a suggestion that nothing like this could happen on European grounds where such behavior is viewed as unnatural. This prejudice of exemplary them versus uncivilized us reconfirms the applicability of A. Yurchak's (2006) research on the meaning of the idealized West for Soviet citizens to the current post-soviet reality. This perspective opens up another important research frame about the social boundaries in the context of preserving or defending one's home space, which is supposed to be kept clean, as opposed to the alien space across the border where it is not shameful to litter. The question is, then, where does this alien space start and where does the border lie? And what other borderlines are coincident with the exemplary/uncivilized us versus them; the nation state border, the regional or city limits, or one's threshold at the entrance doorway?

\section{Invisible Planters at a Flowerbed}

Drawing a borderline between "insiders" and "strangers" can be discovered even within the tiniest pieces of land involved in municipal ecological campaigns. An exciting event devoted to the planting of decorative flowers in different parts of Petrozavodsk by interested citizens was scheduled for June 16, 2014. I set off on my little "field trip" with an intention to catch two birds with one hand. First, I presumed that this would be a good occasion to learn more about the local residents' perceptions of domestic space, and second, I wished to make my two preschool children to literally dig into a socially meaningful activity that would have an immediate and beautiful result.

The three flowerbeds that we visited were located next to apartment blocks on the outer side of the buildings facing the street. Each flowerbed was taken care of by a different group of people. As it turned out later, they were residents of the immediately neighboring buildings, accompanied by representatives of a community-based organization or a sponsor of planting stock. When our gardening team arrived at the first site, the

21. News "Today the participants of Egon Bahr seminar summarized their work" on 3.10.2014 published at the Petrozavodsk city administration web-site. Available at: http://www.petrozavodsk-mo.ru/petrozavodsk/ index/news/more.htm?id=10753232@cmsArticle (accessed 3.10.2014). 
planting was already underway, and the flowerbed was quite obviously divided into two sections. The sections were not divided into equal portions; rather, they were divided roughly in two-thirds and one-third by the two well-defined groups, with the larger piece of land being occupied by the residents who came to "decorate their space around their own house." ${ }^{22}$ The smaller piece was put at the mercy of another group, either representing workers of an organization that was sponsoring this particular flowerbed (such as Karel'skaya Dacha), or a societal organization (such as Mama) that, besides planting, was rigorously documenting each step of their involvement to produce a video about it as a future post on its VKontakte web-page.

The two distinct groups did not mingle in any of the three planting sites that we visited: our sincere offer of help was not welcomed at any of these sites. I had the impression that my children and I were seen as undesired intruders in a kind of a closed ritual of an almost sacred group; our own inventory (toy shovels and buckets) seemed to have induced irritation rather than admiration. Pushing my fieldwork further, I insisted on the children's participation with a beaming smile, and took great pains to get them involved in at least some kind of small activity, like watering the planted flowers. It should be noted that the problem was not, as might be expected, that I had been labeled as a non-Petrozavodian citizen; rather, the exclusion had to do with the defense of the conquered territory on the part of the participating organizations, or the unwillingness to "let children spoil what I'll look at for years passing by," on the side of the local neighbors. ${ }^{23}$

The NGO side was more welcoming after they discovered a potential benefit from our participation: they were filming the children to include them in their video report about the campaign. The division between the two groups, to the point of not speaking to each other unless the other side had violated the borderline inside the flowerbed, sometimes demarcated with a string, was striking. Every group knew how to plant flowers, but only the residents' groups, largely consisting of elderly women and school children, knew exactly "how to plant flowers at their flowerbed." ${ }^{24}$ The municipal website advertised this event five days in advance and welcomed all interested citizens to participate. ${ }^{25} \mathrm{In}$ his research of insiders and outsiders within one territorial entity, A.V. Shipilov goes in depth into the reasons for the creation of oppositions between us and them, the reasons why the assertion of one's own means the negation of the other's, etc. Citing Ortega y Gasset's book Man and People (1957), the author agrees that "The other can be both a friend and a foe, and that is why any society and any community means also dissociation, the friends and foes living together" (Shipilov, 2008: 10).

22. Quote by V. L., an elderly female resident of the neighboring apartment block who was planting flowers opposite her kitchen window.

23. As stated by S. G., an elderly female resident of a neighboring house.

24. A. D., an elderly woman planting flowers at the intersection between Lenin Avenue and Engels Street.

25. "Anybody who wants to can participate in this campaign. The townsfolk can call the ecology department at city administration in advance at 71-35-72 or 71-35-66 on Monday or come straight to a selected planting site." News published 11.06.2014 on the Petrozavodsk city administration web-site. Available at: http:// www.petrozavodsk-mo.ru/petrozavodsk/index/news.htm?f=61\&fid=2\&blk=10528684 (accessed 11.06.2014). 


\section{Conclusions: Bordering Wastelands}

It is striking how the frames of the border and the borderline stretch and shrink depending on one's perspective or view point. The borderlines expand and contract along many different scales, from the construction of the other along the borderland of the national states and cooperative regions to less visible borderlands that exist within a neighborhood. Such borderlands may be represented by strings cutting across flowerbeds that physically demarcate the divide between individuals of the same nationality and cultural background who need to claim, protect, and reconstruct a personal connection to a piece of land.

Common Nordic values, including green development, education, entrepreneurship, and civic society participation, are evident in international cooperative projects, in the round-tables and seminars held in the Petrozavodsk city administration, and in the course of the local municipal green campaigns with the narrower focus on youth, the local environment, and recycling. Petrozavodsk's relative openness to the western winds and orientation towards its (still) idealized Nordic neighbors allow for a particular susceptibility to the flow of innovations, especially in terms of ideas and technology. These innovations have been extended through the mediating activities of international partners, particularly through the Nordic Council of Ministers, an active promotional and funding body in northwest Russia. After having been imported to the Karelian grounds, some of unconsciously promoted messages and suggestions that accompanied the ideas of sustainability in the Nordic way have become progressively rooted in the local reality, and adapted into the everyday and professional life of citizens. The process of transferring ideas seems to be inseparable from the transfer of practice and technical solutions as well as the learning process. Practical results of the WASTE project, among others, include the systemic changes in the practice of waste treatment on the island of Kizhi.

Another particular outcome of the international cooperative projects in Karelia is that their effects are felt not only in the borderland areas, but also diffused from the Petrozavodsk "hot spot" further on the Russian side of the border to other participants of these projects located further from the border. For example, in the case of the project in question, the territories that benefited from participation were Pskov region and the city of Apatity. The physical crossing of the border by the participants in both eastern and western directions produced particularly fruitful results during the project. Bringing in foreign experts and building upon the reverence felt by locals for western technologies helped dispel possible "legitimacy concerns" regarding the meaning and importance of ecological education and the activism that had been consistently supported by a very limited part of the population.

The historically long and fruitful international partnership in Karelia is realized on numerous platforms. One of these platforms is the Barents Region cooperation arena, whose major objective was declared to be the promotion of "sustainable development in all aspects: economic, environmental and social, and strengthening of comprehensive security in the Region." In this sense, the project WASTE, Waste Awareness: Sorting, 
Treatment, Education, is an exemplary representative of the realization of this objective in practice.

This case study of this project shows how the broadly defined official values of influential neighbors penetrate and find their niche within the set of values held by local Karelian citizens, mixing with purely local ways to establish and maintain one's domestic or alien space, negotiating between the rights and duties of leaders and employees, defining and judging what is appropriate, and what has to be expelled from one's orbit because of perceptions of impurity, or that of being "dirty." Finding common ground on the basis of mutually shared values proves to be vital not only for cross-border cooperation between societies, but even more so, within one's particular society. The Nordic policy of cross-border partnership with Russia, as in this example of a waste management project, demonstrates how the ideological adherence to environmental commitments goes handin-hand with practical benefits, such as opening up a receptive market and sales area for Nordic technologies, facilities and equipment.

As I am writing these lines, these mechanisms keep rolling on, increasingly reminiscent of a growing snowball. The Petrozavodsk municipal website recently put out information on the recent round-table discussion devoted to the future of separate waste management in the city that took place on October 10, 2014, that involved almost exclusively local participants, experts, and society actors, with the exception of a couple of Russian non-Karelian guests. This was a platform for commencing dialogue between the local government officials and NGOs including educators, public activists, and business owners. It is evident now, almost a year after the closing conference of the WASTE project, that it has become an important milestone for further initiatives, and a successful test of the public's readiness to take over. As was noted by Rashid Alimov, a representative of Greenpeace Russia, if 10-15\% of the city population is ready for separate waste collection, the introduction of this technology on the city level becomes relevant. It is fascinating to track these areas of continuing permeability and impermeability of ideas and innovations in the borderlands, to document the direction of the exchanges, and how the crossborder exchanges are adapted in their new contexts.

\section{References}

Bærenholdt J. O. (2007) Coping with Distances: Producing Nordic Atlantic Societies, Oxford: Berghahn Books.

Blake G. (2000) Borderlands under stress: some global perspectives. Borderlands under Stress (eds. M. Pratt, J. A. Brown), London: Kluwer Law International, pp. 11-16.

Belser A. (2004) Officials learn about Swedish “eco-cities.” Pittsburg Post-Gazette, Saturday, May 15, 2004. Available at: http://www.post-gazette.com/pg/o4136/316914.stm (accessed 12.05.2014).

Brunet-Jailly E. (2005) Theorizing borders: an interdisciplinary perspective. Geopolitics, vol. 10, no 4, pp. 633-649. 
Commission of the European Communities (2000) INTERREG cross-border framework, Brussels.

Crandall C. S., Eshleman A., O’Brien L. (2002) Social norms and the expression and suppression of prejudice: the struggle for internalization. Journal of Personality and Social Psychology, vol. 82, no 3, pp. 359-378.

Dellenbrant J. A., Olsson M. O. (1994) The Barents Region: Security and Economic Development in the European North, Umea: Cerum.

Donnan H., Wilson Th. (eds.) (2010) Borderlands: Ethnographic Approaches to Security, Power and Identity, Lanham: University Press of America.

Douglas M. (2005) Purity and Danger: an Analysis of Concept of Pollution and Taboo, London: Routledge.

Esklinen H., Liikanen I., Oksa J. (eds.) (1999) Curtain of Iron and Gold: Reconstructing Borders and Scales of Interaction, Aldershot: Ashgate.

Haas E. B. (1958) The Uniting of Europe, Stanford: Stanford University Press.

Hettne B. (2002) The Europeanization of Europe: endogenous and exogenous dimensions. European Integration, vol. 24, no 4, pp. 325-340.

Hettne B. (2003) The new regionalism revisited. Theories of New Regionalism: A Palgrave Reader (eds. F. Söderbaum, T. M. Shaw), Houndmills: Palgrave, pp. 22-42.

Hettne B., Inotai A. (1994) The New Regionalism: Implications for Global Development and International Security, Helsinki: UNU World Institute for Development Economics Research.

Keating M. (1998) The New Regionalism in Western Europe: Territorial Restructuring and Political Change, Cheltenham: E. Elgar.

Stokke O., Tunander O. (1994) The Barents Region: Cooperation in Arctic Europe, Oslo: Prio.

Stoltenberg T. (1997) Visions of the authors of the Barents Euro-Arctic Region Cooperation: past and future. Europe's Northern Dimension: The BEAR Meets the South (eds. L. Heininen, R. Langlais), Rovaniemi: University of Lapland Press.

Shilov A. (2008) "Svoi," "chuzhie" i drugie ["We," "Them" and Others], Moscow: ProgressTradicija.

Turner N., Davidson-Hunt I., O’Flaherty M. (2003) Living on the edge: ecological and cultural edges as sources of diversity for social-ecological resilience. Human Eco$\log y$, vol. 31, no 3, pp. 439-46o.

Wilson Th., Donnan, H. (eds.) (2012) A Companion to Border Studies, Hoboken: Wiley Blackwell.

Yurchak A. (2006) Everything Was Forever, Until It Was No More: The Last Soviet Generation, Princeton: Princeton University Press. 


\section{Web Sources of Documentations and Policies in the Order of Appearance in the Text}

Nordic Council of Ministers (2014) Norden (Cooperation between the Northern European Countries). Available at: http://www.norden.org/en/about-nordic-co-operation (accessed 13.09.2014).

Nordic Center for Welfare and Social Issues (2013) The Nordic Welfare Model. Available at: http://www.nordicwelfare.org/PageFiles/7117/Nordic_Welfare_Model_Web.pdf (accessed 20.09.2014).

OECD (2008) Sustainable Development: Linking Economy, Society, Environment. Available at: http://www.oecd.org/insights/sustainabledevelopmentlinkingeconomysocietyenvironment.htm (accessed 10.08.2014).

Norwegian Ministry of Finance (2008) Norway's Strategy for Sustainable Development. Available at: https://www.regjeringen.no/globalassets/upload/FIN/rapporter/R0617E.pdf (accessed 15.08.2014).

Norwegian Ministry of Finance (2005) Sustainable Development, National Agenda 21. Available at: http://www.regjeringen.no/en/dep/fin/Documents-and-publications/ Guidelines-and-brochures/2005/Sustainable-Development-National-Agenda-. html?id=419468 (accessed 16.06.2014).

Norwegian Ministry of Foreign Affairs (2012) Priorities for Norway at the UN General Assembly 2012. Available at: http://www.regjeringen.no/en/dep/ud/selected-topics/ un/priorities_assembly67.html?id=699661 (accessed 15.06.2014).

Barents Euro-Arctic Council (2008) Steering Committee on Children and Youth at Risk 2008-2015 (CYAR). Available at: http://www.beac.st/in-English/Barents-EuroArctic-Council/Working-Groups/Joint-Working-Groups/Health-and-Social-Issues/ Children-and-Youth-at-Risk- (accessed 12.10.2013).

OECD (2014) Better Life index. Available at: http://www.oecdbetterlifeindex.org/ (accessed 16.04.2014).

Council of the European Union (2009) 2009 Review of the EU Sustainable Development Strategy - Presidency Report. Available at: http://register.consilium.europa.eu/doc/ srv?l=EN\&f=ST\%2016818\%202009\%20INIT (accessed 5.05.2013).

\section{Сортировка ценностей на Карельском пограничье}

\section{Екатерина Пашковская}

Аспирант факультета антропологии Университета Альберты

Адрес: 116 St. and 85 Ave. Edmonton, Alberta T6G 2R3 Canada

E-mail:pashkovs@ualberta.ca

В данном антропологическом исследовании я рассматриваю процесс пересечения российско-скандинавской государственной и региональной границ в контексте совместного 
социоэкологического проекта по внедрению раздельного сбора отходов в Карелии. В течение этого двухлетнего многоуровнего проекта сотрудничество между Петрозаводским муниципалитетом и его северными партнерами под эгидой Совета министров Северных Стран развивалось, в частности, посредством трансляции и адаптации ценностей, включая раннее обучение и социально-ответственное поведение, что соответствовало специфике приграничных отношений в Баренцевом Евро-Арктическом регионе. Процесс адаптирования Северных ценностей и знаний к повседневной и профессиональной жизни участников проекта шел рука об руку с распространением культурных трансграничных стереотипов. Идея отделения своего от чужого с таким же успехом находит применение и в рамках гораздо меньшей территориальной единицы, такой как кондоминиум или городская клумба, но при условии, что конструирование границы совпадает с осмыслением другого. Невидимые барьеры, так же как и физические объекты, иногда разделяют людей, принадлежащих к одной и той же национальности и обладающих общим культурным опытом, но они могут ощущать потребность утвердить и защитить свою личную связь с определенным участком земли.

Ключевые слова: постсоциализм, переработка отходов, устойчивое развитие, северные ценности, трансляция и адаптация ценностей, конструирование другого, Баренцев ЕвроАрктический регион, Карелия 